\title{
Constructing New Expertise: Private and Public Initiatives for Safe Food (Brussels in the First Half of the Nineteenth Century)
}

\author{
PETER SCHOLLIERS* \\ Free University of Brussels; FOST (Social and Cultural Food Studies), History Department, \\ Free University of Brussels, Room 5C415a, Pleinlaan 2,1050 Brussels, Belgium \\ http://research.vub.ac.be/food-history
}

\begin{abstract}
In 1856, the mayor of Brussels proposed the establishment of a municipal laboratory with a chemist to analyse food and beverages to restrain fraud. His proposal was accepted and a laboratory - possibly one of the first municipal laboratories in Europe - was set up. The laboratory still exists today. This paper aims at tracing the conditions in which it emerged, situating it within the laissez-faire context of the time. It was brought into existence by a liberal administration, in a period of little interventionism replete with unencumbered private interests (those of bakers, butchers, grocers, millers, pharmacists, doctors and so on). What will be considered here is the general mood with regard to food fraud, fair trade, correct price, and the quality of food in the first half of the nineteenth century. On a broader level, this contribution addresses the frictions between private and public initiative, while focusing on the process of construction of expertise. The paper makes use of contemporary documents such as reviews, newspapers, association reports and city council chronicles.
\end{abstract}

Keywords: Food safety, Food analysis, Municipal laboratory, Health policy, Interventionism, Public sanitation

During the meeting of the Brussels city council in April 1856, the mayor advocated the creation of a municipal laboratory for analysing food and beverages to curb fraudulent activities. His proposal was swiftly accepted; funds were granted and staff was appointed. Throughout the nineteenth century, the Brussels mayors all praised the laboratory's performance, which was acclaimed in international meetings and copied by a few European towns. The laboratory still exists today. Its history up until the First World War has already been told. ${ }^{1}$ Here, the focus is exclusively on the 'prehistory' of the

* Email address for correspondence: pscholli@vub.ac.be

Sincere thanks to the staff of the Brussels City Archives for providing very detailed information, and to Michael Whitburn for checking the English.

${ }^{1}$ Peter Scholliers, 'Food fraud and the big city: Brussels' responses to food anxieties in the nineteenth century', in Peter Atkins, Peter Lummel and Derek Oddy (eds), Food and the City in Europe since 1800 (Aldershot: Ashgate, 2007), 77-90; Peter Scholliers and Patricia Van den Eeckhout, 'Hearing the Consumer? The Laboratory, the Public, and the Construction of Food Safety in Brussels (1840s-1910s)', Journal of Social History (2011), $1143-59$. 
laboratory, with one main question being addressed: why, in an environment of unwavering non-interventionism, was a municipal laboratory established, even though for decades pharmacists and chemists had been analysing food, different boards had been tackling food quality, and even though, in particular, the city had created and subsidised a committee of experts for hygiene and food control. Was it that the pharmacists performed poorly or lacked authority, or were the services they provided too expensive? Did the performance of the experts' committee leave much to be desired? On the other hand, did the municipality have sufficient knowledge, funds, contacts and credibility to set up a specialised tool? In other countries, establishing laboratories for analysing food proved problematic as illustrated by the London example. ${ }^{2}$ In Paris, chemists were appointed to the local police to determine food adulteration, and the city's laboratory was not created until $1878 .^{3}$ Amsterdam had a food control service in 1867 that relied on a university laboratory, while some Dutch municipalities appointed local pharmacists to analyse milk and food around $1900 .^{4}$ Other options for analysing food also emerged, such as the Verein gegen die Verfälschung der Lebensmittel (1877) in Germany, a citizen's association that analysed food. ${ }^{5}$ So, under which circumstances did the Brussels municipal laboratory appear in 1856 ?

This theme transcends the local case by far. It touches upon broader issues concerning the economy (fair competition; consumers' interests), ${ }^{6}$ social positions (professional status; income; image), ${ }^{7}$ institutional power relations (local, regional and national governments), ${ }^{8}$ public policy (social peace),${ }^{9}$ scientification processes (the relationship between science and society), ${ }^{10}$ and the intervention of public authorities in matters of health and food (adulteration; quality; classification). ${ }^{11}$ Each of these themes can be situated within different theories (eg. interventionism, civilisation process, politicisation). My own interest here, however, relates more particularly to the construction of expertise,

\footnotetext{
2 John Burnett, Plenty and Want (London: Scolar Press, 1979), 117; Derek Oddy, 'Food quality in London and the rise of the public analyst, 1870-1939', in Atkins, Lummel and Oddy, op. cit. (note 1), 92-3.

${ }^{3}$ Alessandro Stanziani, 'Municipal laboratories and the analysis of foodstuffs in France under the Third Republic: a case study of the Paris municipal laboratory, 1878-1907', in Atkins, Lummel and Oddy, op. cit. (note 1), 105-15; Pierre-Antoine Dessaux, 'Chemical Expertise and Food Market Regulation in Belle-Epoque France', Technology and History, 23, 4 (2007), 353-4.

4 Eddy Houwaart, De hygiënisten, (Groningen: Historische Uitgeverij, 1991), 387; Ingrid Vledder, Eddy Houwaart and Ernst Homburg, 'Particuliere laboratoria in Nederland, Deel 1: Opkomst en bloei, 1865-1914', NEHA-Jaarboek, 62, (1999), 250.

5 Vera Hierholzer, "The "War against Food Adulteration": municipal food monitoring and citizen self-help associations in Germany, 1870s-1880s', in Atkins, Lummel and Oddy, op. cit. (note 1), 117-28.

${ }^{6}$ Michael French and Jim Phillips, Cheated Not Poisoned? Food Regulation in the United Kingdom 1875-1938, Manchester, University Press, 2000, 1-10; Martin Bruegel and Alessandro Stanziani, 'Pour une histoire de la "sécurité alimentaire", Revue d'histoire moderne et contemporaine, 51, 3 (2004), 7-16; Marc T. Law, 'The Origins of State Pure Food Regulation', Journal of Economic History, 63, 4 (2003), 1103-30.

7 Oddy, op. cit. (note 2).

${ }^{8}$ Stanziani, op. cit. (note 3), 110-11.

${ }^{9}$ Scholliers and Van den Eeckhout, op. cit. (note 1).

${ }^{10}$ Lyvia Diser, 'Laboratory Versus Farm: The Triumph of Laboratory Science in Belgian Agriculture at the End of the Nineteenth Century', Agricultural History, 86, 1 (2012), 31-54.

11 Marjatta Hietala, 'Hygiene and the control of food in Finnish towns at the turn of the century: a case study from Helsinki', in John Burnett and Derek Oddy (eds), The Origins and Development of Food Policies in Europe, (Leicester: Leicester University Press, 1994), 113-29; Lucie Paquy, 'Santé publique, répression des fraudes et action municipale à la fin du XIXe siècle: Le Laboratoire grenoblois d'analyses alimentaires', Revue d'Histoire moderne et contemporaine, 51, 3 (2004), 44-65; Hans-Jürgen Teuteberg, 'Food adulteration and the beginnings of uniform food legislation in late nineteenth-century Germany', in Burnett and Oddy, The Origins and Development of Food Policies in Europe, 146-60.
} 
and determining who has influence in the public realm. ${ }^{12}$ This puts the paper within the scope of trading zones (as coined by P. Galison), ${ }^{13}$ or the arena of framing, negotiating and compromising about knowledge and expertise. I wish to contribute to the debate on public regulation, on the basis of theories about the history of public utilities (supplies of gas, water and electricity, road building, sanitation and so on), with particular interest in municipal interventionism (paving the way for state regulation), lobbying activities (against monopolies), and imperfect market functioning (intervening in specific situations). ${ }^{14}$ The paper starts with a section on the setting up of the Brussels laboratory, which includes a brief introduction to contemporary Brussels, an assessment of how food fraud was perceived, and an analysis of the 1856 council debate. Private initiatives regarding food quality and safety in the first half of the nineteenth century are discussed in the next section. There is then a section on interventions by the municipality in matters of food fraud before the existence of the municipal laboratory. Finally, the conclusion appraises reactions to the founding of the laboratory. My investigation has relied on a whole range of very diverse documents such as newspapers, reports by private institutions, semi-official boards, judicial texts, and the city council's chronicles. All these documents were consulted with particular attention being devoted to language (word choice, adjectives, metaphors, silences). My approach may be labelled social constructionism inasmuch as I am particularly interested, on the one hand, in the creation of authority, and on the other, in (debates about) the interference of local government. I therefore consider not only what was argued, but also how it was done.

\section{The Brussels City Council, May 1856}

By 1856, the capital of Belgium had gained international appeal in terms of finance, culture, politics and economy. The local leading circles loved to cultivate this image and were keen to label Brussels a first-rate city. Brussels, however, with its many narrow streets and old, small houses was rapidly becoming inadequate to accommodate a growing population, which resulted in numerous sanitary problems. ${ }^{15}$ One of these problems related to the firm conviction that food was much more adulterated than ever before. ${ }^{16}$ Millers and bakers were suspected of adding chalk, field beans, maize, potato flour, plaster, potash or copper sulphate to bread; the latter in particular caused widespread outrage. Some demanded tougher action given the disappearance of control as a result of the demise of the Ancien Régime. ${ }^{17}$ It is impossible to track the actual food fraud that occurred in

\footnotetext{
12 For the expert's role in decision-making, see H.M. Collins and Robert Evans, 'The Third Wave of Science Studies: Studies of Expertise and Experience', Social Studies of Science, 32, 2 (2002), 236-96.

13 Peter Galison, Image and Logic (Chicago, IL: University of Chicago Press, 1997) [applied by Lyvia Diser, 'Ambtenaren in witte jas. Laboratoriumwetenschap in Belgisch overheidsbeleid (1870-1970)' (unpublished PhD thesis (Leuven University, 2013). See too Michael Gorman (ed.), Trading Zones and Interactional Expertise, (Cambridge, MA: MIT Press, 2010).

${ }^{14}$ For an overview of theories, see Werner Troesken, 'Economic history and competition policy', in Robert Whaples and Randall Parkers (eds), Handbook of Modern Economic History (Abingdon: Routledge, 2013), 82-94.

15 Patricia Van den Eeckhout, 'Brussels', in Martin Daunton (ed.), Housing the workers, 1850-1914: A comparative perspective, (Leicester: Leicester University Press, 1990), 71-2, 85, and 99; Peter Clark, European Cities and Towns, 400-2000 (Oxford: Oxford University Press, 2009), 124, 226.

16 Vera Hierholzer, 'Food security and safety', in Martin Bruegel (ed.), A Cultural History of Food in the Age of Empire (London: Berg, 2012), 68.

17 For example, Victor Vandenbroeck, De l'alimentation publique envisagée au point de vue des fraudes nombreuses et impunies (Mons: Lelouchier, 1853). According to Burnett, this loss of food control caused increasing food fraud in England (op. cit., (note 2), 110).
} 


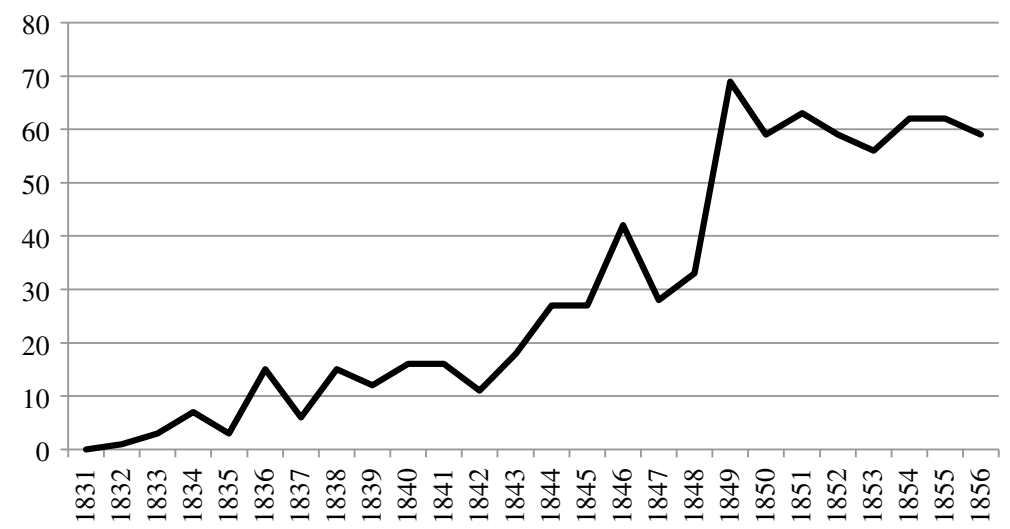

Graph 1: L'Indépendent's attention to food fraud and its control, 1831-56.

that period, ${ }^{18}$ but in order to assess the general state of alertness regarding this fraud and its repression I used the Brussels newspaper L'Indépendant (after 1843: L'Indépendance belge), of liberal tendency, esteemed, and regularly referred to in other contemporary writings. I counted the frequency of two significant word combinations between 1831 and 1856 (pharmaciens + alimentation, and chimiste + fraude). ${ }^{19}$ This yielded 769 hits in 25 years, or roughly 30 per year. Of course, this approach excludes qualitative attention: some word combinations are part of extremely brief, title-less messages simply mentioning, for example, that a chemist has analysed a bottle of wine, but another word combination may be part of a far longer text bearing title and author's name. Graph 1 shows the incidence of these messages between 1831 and 1856: low attention in the early 1830s (less than 10 mentions per year) and moderate rise up till the early 1840s (about 20 mentions); there was then a first peak in 1846 (42 mentions) and a second in 1849 (69 mentions), after which the number remained high (circa 60 per year). ${ }^{20} \mathrm{~A}$ high number of mentions concurred with high food prices in 1846, but not in other expensive years $(1847,1853,1854)$. If these data cannot ascertain the actual increase in food fraud, they definitely reflect growing interest in the phenomenon. ${ }^{21}$

Obviously, the Brussels councillors had no way of referring to such a graph when they debated setting up the laboratory, but by 1856 they must have become quite alert to matters of food fraud, worried as they also were by a great many other issues of public hygiene such as filthy streets, recurrent epidemics or the state of cemeteries. Additionally, rising prices in early 1856 was also a matter of concern to the city's administration. ${ }^{22}$ Rather

18 The same goes, eg. for Great Britain, Anne Hardy, 'Food, Hygiene and the Laboratory: a Short History of Food Poisoning in Britain, circa 1850-1950', Social History of Medicine, 12, 2 (1999), 297.

${ }^{19}$ Using words like 'falsification', 'adulteration' or 'sophistication' and combinations like 'analyse chimique' or 'fraude alimentaire' did not yield consistent results: the former may refer to other items than food products (money, documents, facts, ... ), 'analyse chimique' may refer to criminal investigation, and 'fraude' was hardly used in the newspaper.

20 This confirms the impression of growing food adulteration in England in the same period (Burnett, op. cit. (note 2), 106).

21 Bibliothque royale de Belgique, on-line access (February 2013), http://www.kbr.be/collections/journaux/ journaux_fr.html.

22 'Rapport du collège des bourgemestres et echevins fait au Conseil Communal', Bulletin Communal de la Ville de Bruxelles, (1856), 43, 193: ('Le prix élevé des substances alimentaires réclamait une surveillance plus active'). 
than limiting prices or monitoring trade, the Brussels administration preferred to intervene in an innovative way. The city, then, was governed by a progressive liberal administration with an entirely liberal council, whose aim was to promote Brussels according to modern models (imitating Paris and London), and preferring non-interventionism, which did not preclude a sense of public responsibility. ${ }^{23}$

On April 26th, the Mayor of Brussels, Charles de Brouckère (1796-1860), ${ }^{24}$ gave a short speech in which he proposed the appointment of a chemist and the setting up of a municipal laboratory. His opening line was clear and straightforward: 'The council believes it is indispensable that the municipality should employ a chemist to restrain food adulteration as much as possible'. By using the word 'chimiste' and not 'pharmacien' or 'apothicaire', he differentiated between science and commerce (this distinction will be addressed below). He acknowledged that existing food analyses produced good results, but insisted they took too much time. Moreover, he went on, it was necessary to carry out checks on a daily basis, and he stressed that the head of police would be responsible for the laboratory's operation. ${ }^{25}$ Two councillors reacted briefly to the mayor's speech, while not questioning its baseline. Chemist-pharmacist Jean-Baptiste Depaire $(1824-1910)^{26}$ supported the mayor's view, but stressed that it was not only bread and flour that were adulterated, but other foodstuffs too. Depaire wondered whether it was necessary to appoint a chemist: the creation of a new committee of experts would suffice. D. Kaieman (1796-1857), a lawyer at the Brussels court of appeal, commented further on this appointment: there was the risk of bribery, he said, if only one person was employed. The mayor, then, suggested submitting the proposal to the Section de police (a committee that advised on the police budget), which was accepted.

After a delay of two weeks, the report of the Section stated that the principle of having tougher municipal control of food quality was indisputable. ${ }^{27}$ The recent national law (17 March 1856 - see below) had moreover provided for increasing municipal initiatives in matters of sanitation. With regard to appointing one person or a committee of specialists, the Section de police argued that a committee would only act after complaints had been made, whereas the chemist would work on a daily basis within initiatives taken by the mayor or the police, which could lead to direct legal action. In short, the municipal laboratory would have a preventive character, the chimiste de la ville would not interfere with the dealings of millers, bakers or retailers, and the mayor would be fully responsible. As a result, the Section advised the appointment of a chemist. Nevertheless, a trial period of eighteen months was suggested to evaluate the venture. The mayor, while emphasising the temporary nature of the appointment, added that the appointment would become permanent if the test period proved satisfactory. Five council members (out of

23 Els Witte, 'Gemeenteregies in België (1850-1914)', in L'Initiative publique des communes en Belgique (Brussels: Crédit Communal, 1986), 98.

${ }^{24}$ For the liberal politician, MP (1826-1830), minister (1831-1832), again MP (1848-1860), mayor of Brussels (1848-1860), freemason, and professor at the Free University of Brussels, see Théodore Juste, Charles de Brouckere: bourgemestre de Bruxelles (Brussels: Marquardt, 1867), for a hagiographic account. He presided over the Association belge pour la liberté commerciale, which illustrates his ideological beliefs.

25 Bulletin Communal de la Ville de Bruxelles, I (1856), 293-4.

26 Depaire studied pharmacy and chemistry at Brussels University (1845), had his own pharmacy, advised the public prosecutor of the Brussels arrondissement, was a member of various learned societies, municipal councillor in Brussels (1854-1904), professor (1864-1900), and vice-chancellor (1886-88) at Brussels University (Louis Maricq, 'Jean-Baptiste Depaire', in Bibliographie Nationale (Brussels: Académie royale, 1976), 261-4).

${ }^{27}$ Bulletin Communal de la Ville de Bruxelles, op. cit. (note 25), 314-19. 
twenty-seven) reacted very summarily to this report; they addressed a number of themes: the location and the mode of functioning of the laboratory, the role of the chemist and his relationship with the mayor and the retailers, and how to appoint the chemist. Other, unrelated matters were also addressed. Kaieman feared that the city's chemist would encounter bakers and grocers when accompanying the police, which would endanger his neutral position. The sixth and last debater, Depaire, delivered a slightly longer speech that entirely supported the mayor's proposal. He explained that he had at first feared that the city chemist would interfere directly with the retail trade ('an active control of food retailing') and actually regulate millers, bakers and retailers, but that the words of the Section de police and those of the mayor had appeased him. Immediately after Depaire had delivered his arguments, the council unanimously voted in favour of the proposal. The test period of eighteen months was accepted. A full-time chemist was hired a couple of weeks later. His name was mentioned once in the Bulletin Communal (12 December 1857), but did not appear in a public document, as though this person had to remain anonymous. ${ }^{28}$ The mayor made it clear that he himself would select the chemist. ${ }^{29}$ A budget of 3000 francs was allocated (a salary of 2000 francs for the chemist, plus 1000 francs to cover costs), ${ }^{30}$ whereas the Commission médicale (see below) received only 1800 francs. ${ }^{31}$ The laboratory was set up in the Hôtel de Ville at the Grand'Place (where it remained till the 1880s). The test period did not cause a problem, and up till 1914, the municipal laboratory was given more means and staff, and analysed hundreds of food items every year. ${ }^{32}$ Also, it was referred to as a model for setting up other municipal laboratories in and outside Belgium. ${ }^{33}$

Although the Brussels council was unwilling to immediately take drastic innovative action in matters of food commerce and safety, it appears that decision-making with regard to the laboratory was extremely fast. By contrast, for example, setting up the municipal laboratory of Grenoble took several years. ${ }^{34}$ The Brussels discussion reveals relevant features: no reference was made to practices in other towns or to the opinions of experts (such opinions existed, as will be made clear below), no lobby groups were given any say, ${ }^{35}$ no discussion occurred about the cost of the laboratory or the role of the municipality in interfering with food trade, no discussion took place about staff skills, and no provisions were provided for the laboratory to fit into a judicious sanitation policy. The creation of a

\footnotetext{
28 This chemist was Jean-François Heyvaert about whom no further information appears to be available. In 1864 he was succeeded by Henri Bergé, a professor at Brussels University, author of many books and brochures, freemason, and vice-chancellor of the university in 1878.

${ }^{29}$ Bulletin Communal de la Ville de Bruxelles, 10 May 1856, 319.

${ }^{30}$ In the late 1850 s, a skilled worker earned about 700 francs, an unskilled labourer about 475 francs per year.

31 'Budget de la ville: Nature des dépenses: Dépenses ordinaires: Salubrité publique', Bulletin Communal de la Ville de Bruxelles, 1856.

32 Scholliers, op. cit. (note 1); Scholliers and Van den Eeckhout, op. cit. (note 1).

33 The plea in 1860, for example, by the chairman of the Association générale pharmaceutique in the Council of the province of Brabant, proposing to establish municipal laboratories in Nivelles and Leuven: Dr Gorrissen, Des mesures à prendre pour empêcher et réprimer les falsifications des combustibles, des boissons, denrées ou substances alimentaire quelconques (Brussels: Tircher, 1860), also published in Bulletin de la société de pharmacie de Bruxelles, 1860, with great support. At the international conference on hygiene (Brussels, 1876), the Brussels municipal laboratory was presented and seen as an example for France (Octave du Mesnil, Bureaux municipaux d'hygiène (Paris: Imprimerie Nationale, 1886). These international meetings seemed to have played a role in the creation of the 1905 French law on food quality (Patrick Zylberman, 'Making Food Safety an Issue', Medical History, 48, 1 (2004), 17-18.

${ }^{34}$ Paquy, op. cit. (note 11), 47-8.

35 As opposed to what happened in Paris in the late 1870s; Stanziani, op. cit. (note 3).
} 
permanent service was never questioned, and alternatives (eg. a committee of experts) were barely discussed. It seems that the mayor's proposition was received as self-evident or that - when viewed from a different angle - the rhetoric was convincing: the speeches by the mayor and Depaire had gently convinced the members of the council. In early May 1856, the Brussels administration took a decision that implied radical innovation concerning intervention in matters of food control; it was all as though control was urgently needed and had arisen in a vacuum - a situation which was far removed from daily practices.

\section{Private Initiatives up till 1856: Laissez-Faire (with Some Attention to the Common Interest)}

Since the 1800s at least, chemists, and primarily pharmacists, had played a role in assessing the quality of food. This much was made clear by newspapers, reports by learned societies, brochures by physicians, and, indeed, acknowledgments by the Brussels municipal council. Graph 1 shows the frequency of messages pertaining to food fraud. The role of pharmacists in particular was highlighted in L'Indépendant from 1831 to 1856: a considerable number of newspaper articles announced that a pharmacist had analysed bread, flour, milk, wine or some other foodstuff; that a grocer had been sentenced after a pharmacist has established fraud, or that chemical investigation had revealed considerable food fraud. ${ }^{36}$ These articles report on people taking the initiative in bringing foodstuffs to be analysed by a professional, as if this were common practice. Often, such an initiative would be taken by legal professionals (police officer or mayor), but also by physicians, pharmacists, professors, traders and consumers, or, in one case, by a newspaper. (About the latter: L'Indépendant, 20 September 1838, wrote, 'We did not wish to cause alarm, but yesterday a citizen brought a suspect piece of bread to the newspaper's bureau, and we hurried to show this to a competent chemist.') One testimony in 1840, worrying about careless reactions that lead to food scares, even claimed that 'there isn't a day without citizens bringing bread to a pharmacist to have it analysed' ${ }^{37}$

Were some pharmacists or some chemists in particularly great demand? Did some specialise in analysing food? Or was it, for pharmacists, no more than routine business, known to every citizen? I have searched newspapers for advertisements and tariffs relating to food analysis in the first half of the nineteenth century, but though much advertising can be found, none of it relates specifically to food analysis or a laboratory (only to pills, emulsions or ointments). Did serious pharmacists not advertise $?^{38}$ Was analysing food such a self-evident activity for pharmacists that it did not need to be promoted? Food analysis and laboratory work were not referred to in the lists of occupations in Brussels. These lists or directories contained the names of all the pharmacists with their addresses and, occasionally, qualifications (eg. in 1840: Gripekoven, Grande rue au Beurre, Fournisseur breveté d'eaux minérales de la cour, fabricant de produits chimiques et pharmaceutiques). ${ }^{39}$ The aim of the qualifications was to secure commercial gain,

\footnotetext{
${ }^{36}$ For example, the editions of 20 September 1838, 2; 23 June 1844, 2; 5 October 1855, 2.

37 'Sophistication du pain', Compte rendu des travaux du Comité central de salubrité publique de Bruxelles pendant l'année 1840 (Brussels: Tircher, 1845), vi.

38 An Antwerp physician, pleading for the limitation of the number of pharmacists, referred to charlatans 'whose names appear on street corners and on page four of newspapers' (C. Broeckx, Essai sur la limitation du nombre des pharmaciens en Belgique (Antwerp: De Cort, 1851), 9).

${ }^{39}$ Indicateur belge ou guide commercial et industriel de l'habitant et de l'étranger dans Bruxelles et la Belgique pour l'an 1840 (Brussels: Bouchard-Rinche, 1840), 264.
} 
but also, and perhaps primarily, to delineate the difference between serious chemists or pharmacists and common merchants or swindlers. These lists, incidentally, make it possible to estimate the growth of the number of pharmacists in Brussels in the first half of the century: 36 in 1806, 45 in 1830, 56 in 1840, 60 in 1850, and 73 in $1856 .{ }^{40}$ This corresponded to a $1.42 \%$ annual growth between 1806 and 1856, ie. slightly less than the rise of the Brussels population (1.45 per cent). In 1806, there was one pharmacist for 1900 inhabitants and in 1856, one for 2090 Bruxellois. It is likely, then, that pharmacists were able to deal with the apparently increasing demand for food analysis up till the 1850s, particularly given the fact that some considered one pharmacist for 4000 inhabitants to be sufficient. ${ }^{41}$ Yet, not all pharmacists possessed the equipment to perform analyses. That much was made clear during a debate in the Council of the province of Brabant in 1860, when a member stated that 'Several pharmacists have declared that they do not have the necessary tools for analysing food'. ${ }^{42}$

According to some, the status of pharmacists had deteriorated compared to what it was in the eighteenth century. This appeared very clearly in 1851, in a plea to limit the number of pharmacists, which would guarantee sufficient income, quality of service, and, above all, reliable products. ${ }^{43}$ Serious pharmacists and chemists constantly complained about the many charlatans or ordinary merchants who sold ready-made and cheap pills of all sorts, but were not capable of preparing or providing appropriate medicine. Much was done to discourage charlatans, including ensuring adequate education at university level. The law of 1818 (valid after Belgium's independence in 1830) had created provincial Commissions médicales de l'examen et de la surveillance de tout ce qui a rapport à l'art de guérir responsible for accrediting pharmacists (as well as midwives, ophthalmologists and druggists). The criteria differed depending on the provinces, and candidates had to prepare through personal study; also, at least three years' experience assisting a pharmacist was required. ${ }^{44}$ Academic education in pharmacology was lacking; additionally, the degree of doctor in pharmacology had been abolished in 1835. Around that same year, local associations of pharmacists were set up, and in 1842, an Ecole de Pharmacie was created as part of the University of Brussels (that provided chemistry and toxicology courses, and of which Depaire was one of the first to graduate). ${ }^{45}$ In 1845 , a national journal was launched (Journal de pharmacologie); in 1846, a national association of pharmacists was

40 Almanach de Bruxelles pour l'an 1806 (Brussels: Huyghe, 1806), 347-8; Almanach de poche de Bruxelles pour l'an 1825 (Brussels, 1825), Almanach royal et de commerce de Belgique (Brussels: Balleroy, 1838), 483; Indicateur belge ou guide commercial pour l'an 1840, 264-5; Almanach du commerce et de l'industrie contenant plus de 100.000 adresses de Bruxelles et des provinces. Année 1851 (Brussels: Tarlier \& Stapleaux, 1851), 475; Almanach de poche de Bruxelles pour l'année 1856 (Brussels: Tircher, 1856). I counted the pharmacists with addresses in the city of Brussels itself (ie. not the conurbation); I did not include the few pharmacists working for institutions (hospitals, the army).

41 This proportion was backed by the Congrès médical of Brussels in 1836; in 1851 Broeckx proposed 1 pharmacist to 5000 inhabitants in cities, 1 to 4000 in towns, and 1 to 3000 in the countryside (Broeckx, op. cit. (note 38), 18, 47-8).

42 Gorrissen, op. cit. (note 33), 9.

${ }^{43}$ Broeckx, op. cit. (note 38), 52-5. Similar views had appeared a decade earlier during a session of the Académie royale de médecine ('la profession de pharmacien ... est tombée bien bas' (Bulletin de l'Académie royale de médecine de Belgique, Tome 1 (Brussels: De Mortier frères), 401).

${ }^{44}$ L. Créteur, Lois et règlements sur la pharmacie en Belgique depuis les temps les plus réculés jusqu'à nos jours (Bruxelles: Mayolez \& De Germer, 1870), 132.

45 The programme included chemistry, physics, natural history, theoretical and applied pharmacology, toxicology, and chemical analysis; in 1864, food analysis was introduced as a separate item. In the same year J.-B. Depaire was appointed professor of pharmacy; A. Guislain, 'La Première École de pharmacie de Belgique, 1842-84', Cercle Benelux d'Histoire de la Pharmacie, 56 (1978), 1-9. 
created; and in 1849, university education was, at last, established. The latter implied that pharmacists had to have a university degree. ${ }^{46}$ Yet, all these initiatives remained insufficient to restore the reputation of the profession and, in 1856, the Société royale de pharmacie de Bruxelles was set up whose goals (still) involved getting rid of charlatans. ${ }^{47}$

Was the chemical analysis of food part of this struggle over competence, and did running a laboratory make a difference between serious pharmacists and charlatans? This is where the theory of trading zones and interactional expertise can be tested. A couple of cases show the role of scientific analysis as opposed to amateurism. The Comité central de salubrité publique de Bruxelles was established in 1835 to advise municipal authorities on issues of public health and hygiene. ${ }^{48}$ Alongside lawyers, administrators, architects, and many physicians, the Comité had two pharmacists. It considered a variety of issues including slaughterhouses, the diet of the working classes, public heating during winter, food prices, gin abuse and food quality. ${ }^{49}$ In 1838,1839 and again in 1840, the Comité set up a special section for testing suspect bread. ${ }^{50}$ It appeared that the bread was safe, which prompted the physician J. Dieudonné, the Conseil's secretary, to make some observations about food safety in the capital. ${ }^{51} \mathrm{He}$ was upset by the fact that not for the first time in a couple of years - bakers had been falsely accused of selling harmful bread (he did not say by whom), which was damaging for commonly held beliefs about safe food in general. Dieudonné proposed that the Brussels municipality should send policemen to frequently visit and control millers and bakers; such an initiative would largely appease the inhabitants and dissuade them from all too often relying on the services of a pharmacist to analyse bread. Also, in 1840, Dieudonné relates a most telling episode that perfectly illustrates the conflict between serious work and amateurism. ${ }^{52}$ Le Courrier belge, a Brussels daily, had published an article about a pamphlet that denounced bread adulteration; in so doing, the paper had generated some public anxiety. The author of the article, Kopzcynski, ${ }^{53}$ had analysed bread samples sold in Brussels, and though the samples did not contain copper sulphate, it was revealed that spoiled rye (seigle ergoté) had been used. This, so claimed Kopzcynski, had caused the recent upsurge of gastrointestinal problems. The Conseil saw this as a great opportunity to act resolutely and

\footnotetext{
${ }^{46}$ Guislain, op. cit. (note 45); L.J. Vandewiele, 'Historiek van de pharmacieopleiding in België', Cercle Benelux d'Histoire de la Pharmacie, 56 (1978), 24-30; Hendrik Deelstra, 'De scheikunde aan de universiteiten en hogescholen', in Robert Halleux et al. (eds), Geschiedenis van de wetenschappen in België, 1815-2000 (Brussels: Dexia-Renaissance du livre, 2001), 161-2.

47 'Société royale de pharmacie de Bruxelles', Belgian Science and Technology On Line Resources (BESTOR), http://wiki.arts.kuleuven.be (accessed 16 May 2011).

48 The Comité operated until 1849, when the national Conseil supérieur d'hygiène public was established to counsel the government. The committee was based on the Paris example (Ann La Berge, Mission and Method. The Early Nineteenth-Century French Public Health Movement (Cambridge: Cambridge University Press, 1992), 147).

49 'Rapport sur l'hygiène de l'ouvrier', Annales du Conseil central de salubrité publique de Bruxelles, Vol. I (Brussels: Tircher, 1841), 188-95. Such broad interests were common for hygienists in those days throughout Europe. See, eg., Houwaart, op. cit. (note 4).

50 J. Dieudonné, 'Compte-rendu des travaux du Conseil pendant l'année 1839', Annales du Conseil central de salubrité publique de Bruxelles, Vol. I (Brussels: Tircher, 1841), xxvi.

51 J. Dieudonné, 'Compte-rendu des travaux du Conseil pendant l'année 1840', Annales du Conseil central de salubrité publique de Bruxelles, Vol. II (Brussels: Tircher, 1845), vi-vii.

52 Ibid.

53 Piotr Kopczynski was labelled 'chimiste' in Belgian migration documents (1836); in Brussels he was an unsuccessful inventor (eg. of self-lighting cigars); he left Belgium in 1843; Idesbald Goddeeris, 'Belgique-Terre d'accueil', Revue belge d'histoire contemporaine, 29 (1999), 276; Idesbald Goddeeris, 'Het vestigingsgedrag van romantische ballingen', Revue belge d'histoire contemporaine, 37 (2007), 295.
} 
prove its own efficiency (une belle mission à remplir); if Kopzcynski was right, then the Conseil would grant his findings genuine authority based on the most rigid testing, but if he was wrong, the Conseil would immediately reassure the public about safe bread and, moreover, vigorously defend the bakers' reputation. So, a team of two physicians and two pharmacists, members of the Conseil, was appointed to analyse the bread. It turned out that Kopzcynski had it wrong, which the Conseil made public in rather diplomatic, but in no uncertain terms. More so even, the Conseil re-iterated the suggestion of having a policeman accompany the members of the Conseil when they visited millers and bakers - something that should be done regularly and very openly to appease the general public. The Brussels municipality turned down the proposal, which caused indignation among the Conseil members. ${ }^{54}$ The Kopzcynski-incident illustrates the conflict over authority between serious pharmacists and a random chemist; it also highlights the request for support by the public authority (police presence), which was denied: it was no business of the local police to accompany private persons, even if the latter belonged to a board that advises the city. The Conseil's actions and views clearly demonstrated the awareness that food adulteration was no longer to be detected by simply smelling or tasting: effective control required expert and skilful intervention that went well beyond the mere ability of manufacturers, traders and consumers.

A similar call for professionalisation also appeared in a report by the Académie royale de médecine of 1848. This Académie was established in $1841,{ }^{55}$ and as early as 1842 the status of pharmacists had been addressed when debating their academic degrees. ${ }^{56}$ The 1848 report was the outcome of a request by the government in 1844 to investigate food fraud as well as of two enquiries into food fraud, which were the result of private initiative. ${ }^{57}$ To solve the problem of food adulteration, the Académie noted that, broadly speaking, producers, traders and consumers ought to be aware of modern scientific methods to discover fraud, but that people 'who have no sufficient education' should be able to call upon an expert. The discussion was about the role of the expert. One proposal was aimed at organising national control: the state would appoint chemists specialised in analysing food. Another proposal included appointing pharmacists who would assist the local police when inspecting food manufacturers and retailers. Both proposals called upon (local or national) authorities to intervene. The conclusion of the Académie, however, was not very forceful to say the least: the government might consider appointing experts to control food, though it was stated that current legislation was adequate. Furthermore, the report concluded, though the possibility of food fraud should not be ruled out, the 'experience of most of the members of the Académie shows that cheating in food matters was exaggerated' ${ }^{58}$

The controversy surrounding food fraud and its implications concerning the authorities and public responsibility was particularly highlighted in La santé, Journal d'hygiène publique et privée, Salubrité publique et police sanitaire, published in Brussels from 1849 to 1859 by two doctors assisted by administrators, politicians, professors, journalists,

54 'Examen des grains vendus sur les marchés de Bruxelles', Annales du Conseil central de salubrité publique de Bruxelles, Vol. II (Brussels: Tircher, 1845), 1xviii.

${ }^{55}$ For its history, see Louis Gallez and Léon Gallez, Histoire de l'Académie royale de médecine de Belgique, 1841-1902 (Brussels: Hayez, 1903).

56 'Délibération sur les modifications à apporter à la loi du 12 mars 1818 et 27 septembre 1835', Bulletin de l'Académie royale de médecine (1842), 376-417.

57 H. Mareska, 'Rapport de la Cinqième section sur les falsifications des matières alimentaires', Bulletin de l'Académie royale de médecine (1848), 226-33.

58 Ibid., 231. 
and physicians, all of them members of learned societies or health boards, such as the Académie royale de médicine or the Conseil de salubrité publique. La Santé focused on three areas (les plus urgents de notre époque): hygiene, public health, and sanitation policy. It paid attention to housing, diets, mortality, sanitation, education and food adulteration. With regard to the latter, specific foodstuffs were discussed. For example, in December 1849 it was said that chicory, sold in Brussels, was generally adulterated, but that the additions were not harmful to health (nonetheless, they were illegal and should therefore be prohibited). ${ }^{59}$ More attention to food adulteration arose in 1852, when Victor Vandenbroeck, a physician and professor of chemistry at the Ecole des Mines (Mons, province of Hainault) was warmly supported in his battle against food fraud. ${ }^{60}$ In 1846 , Vandenbroeck had published a brochure in which he had called upon the government to intervene more vigorously in matters of food adulteration. ${ }^{61}$ Since then, Vandenbroeck had campaigned vigorously in favour of strict food control and severe penalties, reporting on analyses he had performed, denouncing the real health hazards of adulterated food, and proposing new legal measures. In 1852, La Santé acclaimed the brochure, as well as Vandenbroeck's other initiatives in the same area, and excoriated the fairly mild punishments inflicted on manufacturers and traders who were caught red-handed.

The attention that was paid to Vandenbroeck's brochure in La Santé occurred in the context of the international Congrès d'hygiène held in Brussels in $1852 .{ }^{62}$ A special section of this meeting was devoted to food adulteration. It was there that Vandenbroeck held a speech in which he presented rather radical views. ${ }^{63}$ La Santé supported him unreservedly, and published the doctor's speech exhaustively. ${ }^{64}$ Vandenbroeck claimed that he had investigated food fraud since 1843 and was probably the best-informed person on the subject in Belgium. Two issues were at stake: fair trade and public health, on which current laws (not only in Belgium) were inadequate. Vandenbroeck argued that stricter laws were badly needed, though new laws would not be enough. First, honest manufacturers and traders should be rewarded: when chemical analyses proved that their products were unadulterated, it should be made public, 'like an advertisement'. ${ }^{65}$ Conversely, when manufacturers and traders were caught in the act of committing fraud, their names and addresses should be published in local and national newspapers. An equally radical new suggestion proposed establishing chemical laboratories for analysing food, 'where each citizen could present food, under a guarantee from the municipal administration; this analysis would be free for the poor' ${ }^{66}$ Four preventive actions were proposed at the end of the deliberations on food adulteration: the obligation by the communes to strictly observe the legislation; the establishment of local health committees; the obligation for merchants to allow the police to carry out inspections and take food samples, and the establishment of local laboratories for food analysis. ${ }^{67}$ These proposals were unanimously adopted (after

\footnotetext{
${ }^{59}$ La Santé, December 1849, 131-2.

${ }^{60}$ La Santé, December 1852, 127-30.

61 Victor Vandenbroeck, De l'insuffisance des lois actuelles pour empêcher les falsifications des matières alimentaires (Brussels: Parent, 1846).

62 This meeting was held from 20 to 23 September, with 300 Belgian and 57 foreign participants (Conseil general d'hygiène de Bruxelles: Compte rendu des séances: Textes des résolutions votées (Brussels: Stapleaux, 1852)).

63 Conseil général d'hygiène, op. cit. (note 62), 107-16, 256-8.

${ }^{64}$ La Santé, op. cit. (note 60).

${ }^{65}$ Conseil général d'hygiène de Bruxelles, op. cit. (note 62), 110.

${ }^{66}$ Conseil général d'hygiène de Bruxelles, op. cit. (note 62), 106.

${ }^{67}$ Conseil général d'hygiène de Bruxelles, op. cit. (note 62), 257.
} 
some debate about whether the analysis of food would be free for all citizens, which was not accepted). It was not mentioned who should establish and pay for the laboratories, but the role of municipalities was obvious.

As mentioned above, La Santé reproduced this speech. However, when it came to the conclusions, only three of the four were mentioned: no mention was made of the proposal to create municipal laboratories. Why not? Was setting up a laboratory in every town inconceivable? Some participants were in favour of free analyses, but Vandenbroeck himself argued during the debate that this would leave the door open for anybody to have his butter or bread tested: 'You'll need an army of chemists and a mass of laboratories'. Maybe La Santé's reluctance can be explained by financial considerations. This financial aspect (ie. the burden for public authorities) re-appeared in an article of 1858, in which La Santé warned that most communes would find it impossible to pay the salary of a chemist. ${ }^{68}$ In sum, La Santé seems to have favoured more control by public authorities, while at the same time remaining hesitant with regard to increasing public intervention. A decade later, the proposals of the 1852 Congrès d'hygiène, including the setting up of municipal laboratories for food analysis, were still being supported. ${ }^{69}$ Vandenbroeck was still determined, even though he had tempered his more radical views. In 1853, he published a leaflet in which he accused the law of being too permissive (fines for food fraud were the same as those applied for not keeping one's dog on a leash). ${ }^{70}$ Also, he proposed a new law to 'prevent and discover food fraud' that no longer relied on municipal laboratories, but on provincial committees of three experts that would immediately analyse 'any foodstuff provided by any legal authority whatsoever'. His proposal was never discussed.

The silence surrounding the setting up of chemical laboratories was not due to the journal's lack of interest in matters of food fraud. On the contrary, the table of contents between 1849 and 1855 shows a growing interest in these issues (from one reference to seventeen). In 1853, La Santé ran a series about food adulteration (one article every month), ${ }^{71}$ while the publication reported on the development of the Brussels administration in its struggle against food adulteration. When, in 1854, the annual report on Brussels was published (see below), which revealed food analyses that were reassuring, La Santé concluded that communes should do whatever was needed to eradicate the 'abuse of chemical progress' (user de toute leur autorité pour réprimer cet abominable abus des progrès de la chimie). ${ }^{72}$ The latter was a new concern. La Santé frequently mentioned the 'progress of chemistry' by which the journal meant 'monstrous sophistications', 'a shame for the food industry', 'slow but permanent murder', and a 'crime in disguise' ${ }^{73}$ These were all references to fast evolving food manufacturing that had started to introduce additives (colouring, conservation, or taste enhancing) without any regulatory restraint all of which were practices that differed from the 'familiar' adulteration of the recent past. It was no longer clear what adulteration really was. This became a major problem in the second half of the nineteenth century. Pharmacists, so La Santé predicted, were confronted with a huge task: they would have to assist medicine in its battle against food alteration. ${ }^{74}$

68 'Falsification des denrées alimentaires', La Santé, September 1858, 51.

69 J. Squillier, Traité populaire des denrées alimentaires et de l'alimentation, (Brussels: Tarlier, 1863), 402-5.

70 Vandenbroeck, op. cit. (note 17).

71 'Falsifications des substances alimentaires', La Santé, April 1853, 221.

72 'L'état sanitaire de la ville de Bruxelles', La Santé, October 1854, 87.

73 'Sophistication des denrées alimentaires', La Santé, December 1854, 134-5.

74 'Devoir des pharmaciens en présence des falsifications', La Santé, December 1856, 144. 
La Santé kept a close watch on how the municipality of Brussels handled food adulteration. Weak interventions were rebuked, as appeared clearly in a comment on a session of the Brussels council of September $1854 .^{75}$ The mayor had explained that he had ordered the testing of 119 bread samples, 63 of which contained bean flour in relatively small quantities. The mayor had no alternative but to reprimand the miller, but did not go so far as to take him to court. La Santé was outraged and accused the mayor of weakness. The magazine did not demand other measures be taken (eg. frequent police visits to food retailers or the setting up of a municipal laboratory) beyond the strict application of the law. When, in May 1856, the municipal laboratory of Brussels was created, La Santé made no comment (lack of awareness, maybe). The law of 17 March 1856 on the curbing of food adulteration, however, did get some attention: it would not work, argued La Santé, because most communes could not pay for adequate chemical analysis, which is why food control should be organised at the level of provinces. ${ }^{76}$ This also became Gorrissen's concern when, in 1860, he proposed to the Council of the province of Brabant the establishment of municipal laboratories based on the Brussels model. His speech severely criticised the law of 1856 for not providing for scientific backing of chemical analyses, which led to some communes in Brabant not analysing food. ${ }^{77}$ In some respects, the 1856 law was more lenient than that of 1829 (eg. in terms of punishment), and in general more attention was paid to trade relations than to food safety. ${ }^{78}$

So, when in May 1856, the Brussels council adopted the mayor's proposal to set up a city laboratory, decades of growing attention to food fraud had gone by. Physicians, chemists and pharmacists, that is new experts (vis-à-vis the traders, manufacturers and consumers), analysed food frequently; they published many leaflets and books, appeared in the media, proposed new measures and eagerly sought to achieve recognition. In short, private initiative was very present. Often, proposals implied the more or less discrete presence of some form of public authority, as though private initiatives ought to be backed by higher power, and on a rare occasion the latter even referred to substitution of private by public initiative. Yet, weak legislation and inadequate police action were also blamed.

\section{The Brussels Council Prior to 1856: Pragmatism Rules}

Since the 1830s, the Brussels administration had been sensitive to all matters linked to food fraud: it was highly aware of the problem of correct trade, health, and public trust and order. The municipality could refer to various laws on pure food and correct trade, which had existed since the Southern Netherlands had been part of the French Empire (1794-1814) and of the United Kingdom of the Netherlands (1815-30). Laws of 1790, 1791,1810 , and particularly 1829 , explicitly allocated the control of food trade to the communes, but gave rather vague definitions of fraud ('addition of dangerous ingredients' and, later, 'addition of damaging or poisonous matters'), and dealt with the task of policing,

\footnotetext{
75 'Falsification des denrées alimentaires', La Santé, January 1855, 161-2.

76 Ibid., September 1858, 51.

77 Gorrissen, op. cit. (note 33), 8-9 (Gorrissen was a pharmacist in the city of Brussels, a teacher of industrial chemistry, an inspector of the city's hospitals, and a member of the Commission médicale locale (see below for the latter). Other contemporaries also considered the law to be inefficient: it was too weak and too vague (eg. Squillier, Traité populaire, op. cit. (note 69), 405).

${ }^{78}$ Carl Kestens, Voeding en recht: Historische en juridische inleiding op het voedingsrecht (Bruges: Die Keure, 1990), 69.
} 
punishment and the appointment and aptitude of experts. In 1836, a new communal law extended the responsibility of communes, allowing them to take measures regarding food safety. ${ }^{79}$

Since the mid-1840s, and most likely in connection with rising prices in 1846 and 1847, which caused growing general interest in safe food, the Brussels mayor reported annually on food adulteration, mostly to reassure the council and the citizens about food quality in the city. Thus, in the 1849 Rapport annuel on the situation of the city it was noted that, 'several analyses had been performed, at the request of private persons or the Administration, and carried out with the greatest care; no sophistication had been detected' ${ }^{80}$ It was not mentioned who these 'private persons' were (traders, ordinary consumers, physicians or other people or institutions); neither was it mentioned why and under which circumstances the Administration took the initiative to request food analyses. No statistics were made available (number of tests, results or sorts of food). Reassuring, short notes appeared in following years as well. In 1850, it was said that no food adulteration had been detected, but that a professor at the Ecole des Mines of Hainault (most likely, the above-mentioned Vandenbroeck) had warned against the use of harmful wrapping paper. ${ }^{81}$ In 1851 and 1852, it was once again reported that no adulteration had been found. ${ }^{82}$ In 1852 , however, this trouble-free image could no longer be maintained. The report revealed that the baker Rotsaert had used copper acid, for which he was sent to prison for two years. ${ }^{83}$ It may come as a surprise at this stage that the resolutions with regard to food fraud of the 1852 Congrès d'hygiène were not referred to in the city council, although these involved relevant discussions about municipal action. In 1853,1854 and 1855 , the annual reports once more noted that no adulteration had been detected.

Particular events however occurred in those years, which revealed new concerns and led to new initiatives. In 1853, the mayor deemed it necessary to mention (due to 'the extreme gravity' of the case) that he had been requested by a miller to explicitly state in the city council that the police had definitely not visited the miller's workshop. The miller was worried about rumours that accused him of adding ingredients to his flour. The mayor confirmed that, 'until now, there is no reason to believe that this miller mingles ingredients' (but why 'until now'?). The mayor ended by stressing that, 'our eyes are wide open, because fraud may become common in this year of high prices' ${ }^{84}$ The other relevant occasion sheds light on the mode of analysing food. The 1854 report mentioned that the Commission médicale had performed several food analyses (see below), but that 'the city Administration, in turn, has conducted in-depth control of all flour that is used for bread, which showed that only the flour of beans had been added' (which was penalised). This analysis was performed 'thanks to the unofficial intervention [intervention officieuse] of a member of the Council'. ${ }^{85}$ The member concerned was J.-B. Depaire, who had been invited by the mayor to perform the test. It appeared that out of 119 samples, 56 were

\footnotetext{
${ }^{79}$ Kestens, op. cit. (note 78), 58-66.

80 'Rapport du Collège des bourgmestres et échevins fait au Conseil communal', Bulletin Communal de la Ville de Bruxelles (1849), 214.

${ }^{81}$ Ibid., (1850), 34.

82 Ibid., (1851), 244, and (1852), 232.

83 Ibid., (1852), 232.

84 Session 22 November 1853, Bulletin Communal de la Ville de Bruxelles (1853) 494.

85 'Rapport du Collège: Salubrité publique: Police médicale', Bulletin Communal de la Ville de Bruxelles (1854), 260.
} 
pure $(47 \%)$, while all the others contained beans to various degrees. ${ }^{86}$ But why did the mayor not ask the Commission médicale to perform the test? Could the reason have been a conflict of interests between the authorities?

It is not clear when the Brussels Commission médicale was created, but it existed in 1830, and included physicians, pharmacists, and other experts. ${ }^{87}$ According to the law of 1818, a local Commission could take over particular tasks from the provincial medical committee, and advise it on a wide variety of sanitary issues. Initially, the local Commission was granted 1500 francs per year by the Brussels Administration for everyday costs (meaning that the municipality did not pay staff), which was increased to 1800 francs in 1856, the year when the municipal laboratory was established (the sum remained unchanged until 1873, when it was raised to 2400 francs until 1914). ${ }^{88}$ Two of the tasks of the Commission médicale are relevant here: the control of pharmacists and concern with regard to food quality. Annually, it was reported that all pharmacists of Brussels had been carefully inspected, and that some apothecaries were in need of particular attention. ${ }^{89}$ In 1851, the annual report went further, when the names of defective pharmacists were mentioned. ${ }^{90}$ In rare cases, the condition of the pharmacy was judged excessively bad, which led to its closing. Such messages appeared annually in the 1850s (even after the obligation for pharmacists to have a university degree), though they never gave information about the nature of the inadequacy. The fact that all Brussels pharmacists were inspected every year says much about the image of the profession: did the city administration doubt the pharmacists' abilities, or did it question the remedies and ointments that were sold? No other profession was controlled in such a way. The Commission médicale also dealt with the prohibition of advertising and selling of specific remedies (remèdes secrets) as well as with arbitration between pharmacists and customers. ${ }^{91}$

Repeatedly, the Commission médicale performed food analyses. It appears that all reassuring reports by the city's Administration in the 1840s and 1850s were based on the Commission médicale's checking of food samples. The 1849 annual report of the city council mentioned that in 1848 the Commission had conducted various tests on bread at the request of private persons and the city council; very small quantities of chalk had been discovered in the flour, which had been reported to the legal authorities. ${ }^{92}$ Private persons brought food samples to the Commission: why would they have done this? Did the committee have a fixed location or were the names of the members known? How did people know about this possibility? I found no trace of the Commission's work being publicised. Even more relevant: were people suspicious of local pharmacists? Or would food analysis be a very costly and highly qualified activity, which could only be performed

\footnotetext{
86 This was reported by La Santé (January 1855,161 ), which seized the opportunity to criticise the weak attitude of the city's administration.

87 A Commission médicale provinciale, siégeant à Bruxelles existed in 1820. About the local medical committees, see Rita Schepers, De opkomst van het medisch beroep in België, (Amsterdam: Rodopi, 1989), 59-60. In 1856, the Brussels committee consisted of twelve members, among whom three were pharmacists (Gorrissen, Van Tilborgh, and Dam; none of them were members of the Brussels municipal council); Almanach de poche pour l'année 1856 (Brussels: Tircher, 1856), 223.

88 'Budget de salubrité publique', Bulletin Communal de la Ville de Bruxelles, II (1852) 88; 'Budget de la ville: Nature des dépenses', Bulletin Communal de la Ville de Bruxelles, 1856-1913.

${ }^{89}$ For example, 'Rapport du Collège: Salubrité publique: Police médicale', Bulletin Communal de la Ville de Bruxelles (1849), 214.

${ }^{90}$ Ibid., (1851), 244.

91 Ibid., (1855), 148-9.

92 Ibid., (1849), 214.
} 
by a handful of expensive pharmacists? This, then, highlights social inequality with regard to safe food. ${ }^{93}$ The fact remains, however that private persons knew about the possibility of having food analysed by the Commission. Moreover, to have food analysed under the authority of the city council seemed to have been appreciated. Unfortunately, it is impossible to know how many analyses were performed in those years, or who took the initiative (the council, the police, or consumers), nor which foods were analysed.

Generally speaking, the Brussels Council appreciated the activities of the Commission. The 1849 report stated that, 'The Commission médicale continued to ensure with laudable vigilance the enforcement of the laws on the medical arts'. ${ }^{94}$ During the mayor's speech in April 1856, the sentence that immediately followed the proposal to set up the municipal laboratory, referred to the Commission in these terms: 'We cannot but admire the support of the local Commission médicale' ${ }^{95}$ La Sané also wrote very favourably about the Brussels initiatives. ${ }^{96}$ So, why not continue to use the services of the Commission médicale and possibly even extend them in 1856 ? What was wrong with the Commission? It certainly did not have a very visible presence: not once did I find it mentioned in La Santé, the Conseil de salubrité publique, L'Indépendant or any other Brussels paper.

The way the Commission médicale operated was not explained in the Bulletin Communal (nor did I find the modus operandi elsewhere). The members of this committee performed the analysis, as was mentioned in the 1856 report of the city council. ${ }^{97}$ The whole process of analysing food, however, was fairly time-consuming, as was made clear on several occasions. On 2 January 1840, Dr Dieudonné was summoned by three persons who became ill after eating bread. Dieudonné examined the bread and brought it to the Conseil central de salubrité publique de Bruxelles to have it analysed. In its session of 8 January, the Conseil decided to send the bread to a special committee of three pharmacists, who did not detect any fraud. It was not mentioned when the three pharmacists reported the result of the analysis; even so, one week had passed between the allegation and the decision to have the bread analysed. Even more time went by in another case. In January 1849 , V. Vandenbroeck was invited by the municipality of Mons to control the local food quality. With the help of three colleagues, he started his investigations on 24 February, and completed them on 8 August (eight in twelve samples of bread turned out to be adulterated). ${ }^{98}$ The time needed for analysing food, was addressed in the mayor's speech in April 1856: having said how much the activities of the Commission médicale were appreciated, he continued by saying:

When an allegation is uttered, we need the analysis within the day. As it is now, we bring the bread to the Commission médicale that instructs one of its members who, two to three days later, performs the analysis and writes a report to the chairman, who then forwards it to us. ${ }^{99}$

In his brochure of 1860, Gorrissen also criticised this inefficiency, adding that the Commission médicale only convened irregularly, hardly took initiatives and had no more

\footnotetext{
93 Social inequality with regard to food quality was common in this period: it was generally accepted that the poor had to make do with the poorest and cheapest food, as eg. testified by the often cited 'Mémoire sur la condition des classes ouvrières et sur le travail des enfants', in Compte-rendu des travaux du Conseil central de salubrité publique de Bruxelles, Vol. 3 (Brussels: Tircher, 1846), 264. See, too, Burnett, op. cit. (note 2), 115-16.

94 'Rapport du Collège des bourgmestres et échevins fait au Conseil communal', op cit. (note 80).

95 Ibid., (1856), 293.

96 'L'État sanitaire de la ville de Bruxelles', La Santé, October 1854, 87-8.

97 'Rapport du Collège des bourgmestres et échevins fait au Conseil communal', op cit. (note 80), (1856), 43.

98 Vandenbroeck, op. cit. (note 17), 6.

${ }^{99}$ Bulletin Communal de la Ville de Bruxelles, I (1856), 293.
} 
than a purely advisory role. ${ }^{100}$ In 1856 , it was emphasised that the establishment of the municipal laboratory would do no harm whatsoever to the 'general surveillance of the Commission médicale and the valuable action of this illuminated group; rather, this group will support with more strength the relentless action of the police'. ${ }^{101}$

\section{Conclusion: Progressive-Liberal, Pragmatic and Authoritative Interventionism}

Prior to 1856, pharmacists and chemists analysed food at the request of citizens and institutions, or on their own initiative. This attention should be linked to rapidly increasing awareness of food adulteration in those years, which was caused by urbanisation, the lengthening of the food supply chain, increased competition, profit, and the deregulation of previous control systems. The pharmacists' work was generally praised by the media and learned circles. So, around 1850, as in any other European city, there did not seem to be an urgent need to create a municipal laboratory, all the more since the city administration used the services of a committee of experts (the Commission médicale), which regularly performed food analyses. When in 1856, the municipal laboratory was created, three distinct regimes of food control thus co-existed: private pharmacists, semiofficial board(s) of experts, and municipal action. These regimes competed (as illustrated by the Kopzcynski case in the early 1840s or the extra check by Depaire in 1854), but also negotiated and sometimes collaborated (as shown by Vandenbroeck's proposals in 1852), thus creating new criteria for food safety. This exemplifies the theory of the trading zone of expertise. Together, it highlights the specific position of Brussels within Europe where trading zones of expertise were dominated by one of the actors. In this, Brussels did not imitate London or Paris, but showed the way. In France, around 1850, the expert committee was successful, with private physicians mandated by the local administration, but no direct municipal interventionism; the same goes for Dutch communes fifty years later. ${ }^{102}$ In England, around 1850, health laboratory provision was typically very patchy and 'provided largely on a commercial basis by hospitals and independent laboratories'. ${ }^{103}$ The Brussels example nuances the view that public intervention in this field occurred rather late, whereas the apparently distinct initiative of the city administration backs theories of imperfect market functioning regulations.

Indeed, a key argument of the mayor's speech in 1856 referred to time. He insisted on daily interventions and instant reactions and, apparently, the actual practice of food analysis in those days could not guarantee fast intervention. This, however, was a necessity in a city that was confronted with a growing number of inhabitants, more retailers and merchants, rising prices, and more risk of fraud. Too long a time span between rumours or allegations of fraud on the one hand, and control and result of the analysis on the other, was jeopardising two major factors of the nineteenth-century city: business reputations and social peace. The municipal laboratory of Brussels may thus be seen as a step toward efficiency. To obtain the latter, it was not enough to call upon existing expertise, but new expertise had to be created. The latter materialised quite pragmatically and in mediation with existing expertise: two nicely argued and short speeches were enough to convince the Brussels councillors. Nevertheless, although the setting up of a laboratory did not result from a clear, pre-set ideological plan, ideology was very present in as much as a

\footnotetext{
100 Gorrissen, op. cit. (note 33), 6.

101 'Rapport sur la ville de Bruxelles', Bulletin Communal de la Ville de Bruxelles, (1856), 193.

102 Paquy, op. cit. (note 11), 50; Vledder; Houwaart \& Homburg, op. cit. (note 4).

103 Hardy, op. cit. (note 18), 304.
} 
chemist (and not a pharmacist) was chosen and that the political environment was ideal to create this type of interventionism. This new expertise had legal authority, because the municipal chemist operated under direct supervision of the mayor and the chief of police, thus tightening the process of legal control, which is another element of efficiency.

Since the early 1840s, several people and circles had demanded tougher public intervention, but presumably they did not expect the city's radical initiative. The Brussels municipality had considered that private initiative was unable to solve a problem that could only be addressed within a context of public and legal authority. To what extent this laboratory actually solved the problem of food fraud is another issue that cannot be dealt with here; yet, the psychological impact was important: the city's chemist definitely had more power than most of his colleagues with a private officine, who also had a commercial image. The Brussels municipal laboratory should be situated within the canvas of increasing public interventionism in the second half of the nineteenth century, although it certainly cannot be seen as the outcome of a linear, well-advised process that fits within a master sanitation plan: during the nineteenth century the laboratory was questioned; it performed only weakly in particular periods, and its financing, although growing, did not concur with the general rise in the city's finances. ${ }^{104}$ Certainly, without the progressiveliberal views of de Brouckère and his colleagues, Brussels would never have had this type of institution.

${ }^{104}$ Scholliers and Van den Eeckhout, op. cit. (note 1). 